\title{
Analysis of pulsotypes of salmonella typhi isolates and their clinical profiles in typhoid fever patients
}

\author{
Retno Kadarsih Soemanto, Lucky Hartati Moehario
}

\begin{abstract}
Abstrak
Studi penentuan genotip (pulsotip) terhadap isolat-isolat Salmonella typhi (S. typhi) telah dilakukan menggunakan elektroforesis medan listrik berpulsasi (PFGE = Pulse-Field Gel Electrophoresis). Penelitian ini bertujuan untuk mempelajari diversitas genetik dan hubungan antara karakter genetik dengan manifestasi kliniknya. Sebanyak 66 isolat S. typhi yang berasal dari kasus demam tifoid yang dirawat di rumah sakit telah dianalisis. Empat isolat ditemukan identik dan hasil konstruksi dendogram menunjukkan terdapatnya 33 pulsotip dimana 13 di antaranya dapat dipisahkan dalam 30 subtip. Keragaman genetik di antara mereka relatif tinggi yang ditunjukkan dengan koefisien Dice 0,486-1,000. Pada derajat similaritas 65\%, analisis sidik gerombol menunjukkan adanya 2 sidik gerombol utama, sehingga timbul dugaan bahwa S. typhi yang beredar bukan berasal dari klon tunggal. Pada derajat similaritas $90 \%$, dari 9 sidik gerombol yang beranggotakan $\geq 3$ isolat, didapatkan manifestasi klinik yang sangat bervariasi dari ringan sampai berat tersebar diantara 9 sidik gerombol tersebut. Walaupun data rekam medis yang didapat kurang lengkap, 2 dari 4 pasien demam tifoid dengan S. typhi yang berasal dari sidik gerombol 1 memperlihatkan kenaikan total bilirubin yang tidak ditemukan pada 19 pasien yang berasal dari 8 sidik gerombol yang lain. Dengan adanya temuan ini, diduga adanya kemungkinan suatu trofisme pada system hepatobilier dari kuman S. typhi pulsotip $I_{1}$ dan $I_{2}$ yang berasal dari sidik gerombol 1. (Med J Indones 2003; 12: 13-20)
\end{abstract}

\begin{abstract}
A study of genotyping (pulsotyping) of Salmonella typhi (S. typhi) isolates using pulse-field gel electrophoresis (PFGE) methods was performed to examine their genetic diversity, and relationship between genetic characteristics and clinical outcomes. Sixty-six S. typhi isolates obtained from sporadic hospitalized typhoid fever cases were used in this study. Four isolates were found identical and the dendogram constructed showed 33 pulsotypes in which 13 of them can be divided into 30 subtypes. Diversity among them were high as shown by the Dice coefficients that ranged from 0.486 to 1.000. Cluster analysis showed 2 main clusters with $65 \%$ degree of similarity, suggested that they were not originated from one clone. Further, at 90\% degree of similarity, 9 clusters containing at least 3 isolates were determined to explore any possible existence of relationship between genetic profile and particular clinical outcomes. Clinical manifestations ranged from mild to severe were in fact distributed diversely among these clusters. Although the clinical data obtained were incomplete, 2 out of 4 patients infected by the S. typhi belonged to cluster 1 showed an elevation of total bilirubin, whereas it was not found in 19 other patients distributed in other 8 clusters. Even though specific clinical manifestations were apparently not found to relate with particular clusters of genotypes, S. typhi isolates grouped in cluster 1 seemed to show trophism to hepatobiliary system. (Med J Indones 2003; 12: 13-20)
\end{abstract}

Keywords: S. typhi, typhoid fever, Pulsed-field Gel electrophoresis (PFGE)

Typhoid fever is still a major problem in public health in many developing countries. Increase of international travel and mobility of people between neighborhood countries are contributing to the emergence of new clones of $S$. typhi in these countries. Annual incidence of the disease is 16-17 million cases and approximately 600,000 deaths, and neighboring countries such as

Department of Microbiology, Medical Faculty, University of Indonesia, Jakarta, Indonesia
Indonesia, Malaysia and Thailand had one of the highest incidence in the world as more than 1,000 per 100,000 populations. ${ }^{1}$ In Indonesia, the mean annual morbidity rate from hospitals and health centers during the period of 1981-1986 was 13.9 cases per 100.000-population and case fatality rate (CFR) was $2.6 \%{ }^{2}$ In Jakarta, typhoid fever was the second leading infectious disease after gastroenteritis and caused the highest mortality. ${ }^{3}$ S. typhi was isolated from $14.9 \%$ cases in 1984-1990 while S. paratyphi A and other $S$. paratyphi was $3.1 \%$ and $1.0 \%$ respectively. ${ }^{4}$ 
As a systemic disease, typhoid fever affects gastrointestinal tract and also other human organs. ${ }^{5}$ Many factors such as individual immune responses, personal hygiene and environmental sanitations, increasing incidence of antibiotic-resistant strains have been considered to play a role in the outcomes of the disease in which the clinical syndromes vary from mild to severe, and sometimes with complications. ${ }^{6,7,8,9}$ Nonetheless, plasticity of Salmonella chromosomes have been suggested to be associated with bacterial virulence, and the presence of differences in clinical manifestations. ${ }^{7,10}$ Franco et al (1992) ${ }^{11}$ found a unique flagellar type in Indonesian strains designated as j genotype and a phase II variant, z66. Those strains had been isolated from typhoid fever patients with severe clinical signs. Moehario et al, $(1998)^{12}$ also reported different serum reactivity to outer membrane proteins isolated from local $S$. typhi strains in comparison to those reported by other investigators, ${ }^{13,14}$ suggested a possible presence of certain strains in the area which might be related to more severe disease manifestations. Molecular studies of this microorganism using pulsed-field gel electrophoresis (PFGE) suggested that a certain PFGE type (pulsotype) of $S$. typhi was associated with the ability to cause fatal disease. ${ }^{15}$ Those studies suggested the existence of characteristic differences of $S$. typhi that might be responsible to the presence of various clinical outcomes of typhoid fever. However, relationship, if any, of the symptoms of the disease and genome characteristics of $S$. typhi is still unclear, and thus needed to be elucidated. In this study, we examined 66 S. typhi isolates from sporadic hospitalized typhoid fever cases using PFGE methods, and analyzed clinical manifestations from each patients to observe possible relationship between the pulsotype profiles and clinical outcomes.

\section{METHODS}

\section{Samples}

Sixty-six $S$. typhi isolates were obtained from Dr. RHH Nelwan, Department of Internal Medicine, Medical Faculty, University of Indonesia, Jakarta. The isolates were originated from sporadic cases of typhoid fever admitted in Persahabatan Hospital Jakarta in 1998. From each of these cases, clinical data that included clinical symptoms, laboratory findings and complications of the diseases were obtained from Medical Record Department of the Hospital. ${ }^{16}$ Values of laboratory findings were as shown in table 4. Confirmation tests were carried out for all $S$. typhi isolates using biochemical and serological techniques. Antibiotic susceptibility tests were performed by disk diffusion method according to NCCLS standard. ${ }^{17}$ Antibiotics used were as follows: amoxycillin, amoxycillin-clavulanic acid, chloramphenicol, trimethoprim-sulfamethoxazole, ciprofloxacin, ceftriaxone.

\section{PFGE and Genome Analysis}

Chromosomal DNA was prepared as described by other investigators, ${ }^{18,19}$ and electrophoresis of $\mathrm{Xba \textrm {I }}$ digested chromosomal DNA was conducted as described by Moehario and Soemanto. ${ }^{20}$ Gels were stained with ethidium bromide, destained and photographed under UV light. PFGE patterns were assessed as previously described, ${ }^{21,22,23,24,25,26,27}$ interpretation of gel patterns was based on criteria described earlier by Tenover et al. ${ }^{27,28}$ and Zadoks et al. ${ }^{29}$ Isolates showing the same PFGE pattern or differing by one to three bands were grouped in a same type (clone), isolates that differed in up three bands were classified in subtype. Different but closely related types were grouped if isolates differed by four to six bands and different or unrelated types were assigned if differed by seven bands and more. All of those types were then compared by calculating similarity coefficient Dice. ${ }^{30,31}$ Electrophoretic patterns were analysed for relatedness using a computer program Numerical Taxonomy and Multivariate Analysis (NTSYS-pc) version $1.80 .^{31}$ Dendograms were constructed by using Dice coefficients and clustering by using unweighted pair group arithmetic means method (UPGMA). ${ }^{31}$

\section{RESULTS}

All 66 S. typhi isolates were sensitive to antibiotics tested. Not all patients have complete data for clinical symptoms. Out of 66 cases recorded only 44 data were available. The clinical symptoms found were as shown in Table 1: age ranged from 14-74 years old, most of the patients were female $(60 \%)$, days of fever before admissions less than a week (53.19\%), with the following clinical symptoms: fever $(93.18 \%)$, coated tongue $(54.54 \%)$, diarrhea $(43.18 \%)$, constipation (29.54\%), hepatomegaly (22.73\%). Laboratory findings were as follows: anemia $(25 \%)$, leucopenia $(54,54 \%)$, thrombocytopenia (63.64\%), elevated erythrocyte sedimentation rate $(82.86 \%)$, elevated Serum Glutamic Oxaloacetic Transaminase (SGOT) (89.47\%), elevated Serum Glutamic Pyruvic Transaminase (SGPT) (47.37\%), 
hyperbilirubinemia (13.89\%), hypoalbuminemia (56.52\%), and elevated serum alkaline phosphatase $(37.50 \%)$ as shown in Table 2. Complications of the disease were shown in Table 3 , in which pancytopenia, encephalopathy and typhoid hepatitis apparently were the most common.

Table 1. Clinical symptoms of Typhoid Fever patients

\begin{tabular}{clccc}
\hline No. & Clinical symptoms & Cases & \% & n \\
\hline 1. & Cephalgia & 28 & 63.64 & 44 \\
2. & Febrile $\left(>37.2^{\circ} \mathrm{C}\right)$ & 41 & 93.18 & 44 \\
3. & Nausea & 36 & 81.82 & 44 \\
4. & Epigastric pain & 25 & 56.82 & 44 \\
5. & Anthralgia & 12 & 27.27 & 44 \\
6. & Anorexia & 20 & 45.45 & 44 \\
7. & Coated tongue & 24 & 54.54 & 44 \\
8. & Vomitus & 23 & 52.27 & 44 \\
9. & Cough & 20 & 44.44 & 44 \\
10. & Relative Bradycardia & 20 & 44.44 & 44 \\
11. & Diarrhea & 19 & 43.18 & 44 \\
12. & Hepatomegaly & 10 & 22.73 & 44 \\
13. & Constipation & 13 & 29.54 & 44 \\
14. & Ronchi & 5 & 11.36 & 44 \\
15 & Splenomegaly & 1 & 2.27 & 44 \\
\hline
\end{tabular}

$\mathrm{n}$ : Total patient's data recorded

Table 2. Laboratory findings of typhoid fever patients

\begin{tabular}{|c|c|c|c|c|}
\hline No. & Laboratory findings & Cases & $\%$ & $\mathbf{n}$ \\
\hline 1. & Elevated SGOT & 34 & 89.57 & 38 \\
\hline 2. & $\begin{array}{l}\text { Elevated erythrocyte } \\
\text { sedimentation rate }\end{array}$ & 29 & 82.86 & 35 \\
\hline 3. & Thrombocytopenia & 28 & 63.64 & 44 \\
\hline 4. & Proteinuria & 17 & 62.96 & 27 \\
\hline 5. & Hypoalbuminemia & 13 & 56.52 & 23 \\
\hline 6. & Leucopenia & 24 & 54.54 & 44 \\
\hline 7. & Elevated SGPT & 18 & 47.37 & 38 \\
\hline 8. & Normoleucocyte & 8 & 40.90 & 44 \\
\hline 9. & $\begin{array}{l}\text { Serum Alkali } \\
\text { Phosphatase }\end{array}$ & 9 & 37.50 & 24 \\
\hline 10. & Anemia & 11 & 25.00 & 44 \\
\hline 11. & Elevated Amilase & 1 & 25.00 & 4 \\
\hline 12. & Elevated Lipase & 1 & 25.00 & 4 \\
\hline 13. & $\begin{array}{l}\text { Elevated Total } \\
\text { Bilirubin }\end{array}$ & 5 & 13.89 & 36 \\
\hline 14. & Leucocyturia & 2 & 5.71 & 35 \\
\hline 15. & Leucocytosis & 2 & 4.54 & 44 \\
\hline
\end{tabular}

$\mathrm{n}$ : Total patient's data recorded
The XbaI (5'-TCTAGA-3') digested chromosomal DNAs of $66 S$. typhi isolates showed 10 to 20 fragments with molecular weight ranging from $30 \mathrm{~kb}$ to $650 \mathrm{~kb}$, which are in agreement with our previous report, ${ }^{13}$ and had various PFGE patterns. Further, those isolates were classified in 33 different pulsotypes, and 13 of them were showing 30 subtypes (Figure 1). Genetic diversity of these isolates was found to be relatively high, as shown by their $\mathrm{F}$ values: 0.486-1.000. Cluster analysis showed 2 main clusters at $65 \%$ degree of similarity designated as main cluster A, which consisted of 44 isolates, and main cluster B, consisted of 22 isolates. Further, at 90\% homology, 9 clusters designated cluster 1 to 9 , were found and each clusters consisted of 4, 10, 5, 3, $3,3,4,3$ and 3 isolates respectively. Dice coefficients among isolates in each of these clusters were as follows: $\quad 0.941-0.971, \quad 0.882-1.000, \quad 0.865-0.971$, 0.882-0.944, 0.882-1.000, 0.914-0.944, 0.903-0.970, 0.903-0.968 and 0.759-0.966. Pulsotype II was the most frequent type found, consisted of 10 isolates, in which 4 of them were identical ( $F$ value 1.000). Pulsotype VII consisted of 5 isolates, type I, type XXIV and XXVI consisted of 4 isolates each, type VIII, XVIII, XIX and type XXV consisted of 3 isolates each, whereas 2 isolates of type XVIII were actually identical. Type IV, XXIII, XXVIII were consisted of 2 isolates each. Meanwhile, single isolates were observed in type III, V, VI, IX, X, XI, XII, XIII, XIV, XV, XVI, XX, XXI, XXII, XXVII, XXIX, XXX, XXXI, XXXII and XXXIII subsequently.

Clinical features of 9 clusters that shared $90 \%$ degree of similarity were elaborated to find whether there is a relationship between characteristic symptoms of the disease and any particular clusters. The symptoms observed were as followed: fever, enlargement of the liver, leucocyte count, thrombocyte count, SGOT, SGPT and total bilirubin. Cluster 1, type I PFGE, consisted of 4 isolates showed: $100 \%$ fever, $25 \%$ hepatomegaly, $50 \%$ leucopenia, $75 \%$ thrombocytopenia, $100 \%$ elevated SGOT, $50 \%$ elevated SGPT, $50 \%$ elevated total bilirubin (see Table 4). Cluster 2, type II PFGE, consisted of 10 isolates showed: $75 \%$ fever, $25 \%$ with hepatomegaly, $75 \%$ with leucopenia, $62.50 \%$ thrombocytopenia, $87.50 \%$ elevated SGOT, $62.50 \%$ normal SGPT, $100 \%$ normal total bilirubin (Table 4). The clinical features of patients infected with $S$. typhi originated from cluster 1 to cluster 9 were as shown in Table 4. 
Degree of similarity
Cluster F value

$90 \%$ degree of similarity
PFGE type

(Pulsotype)

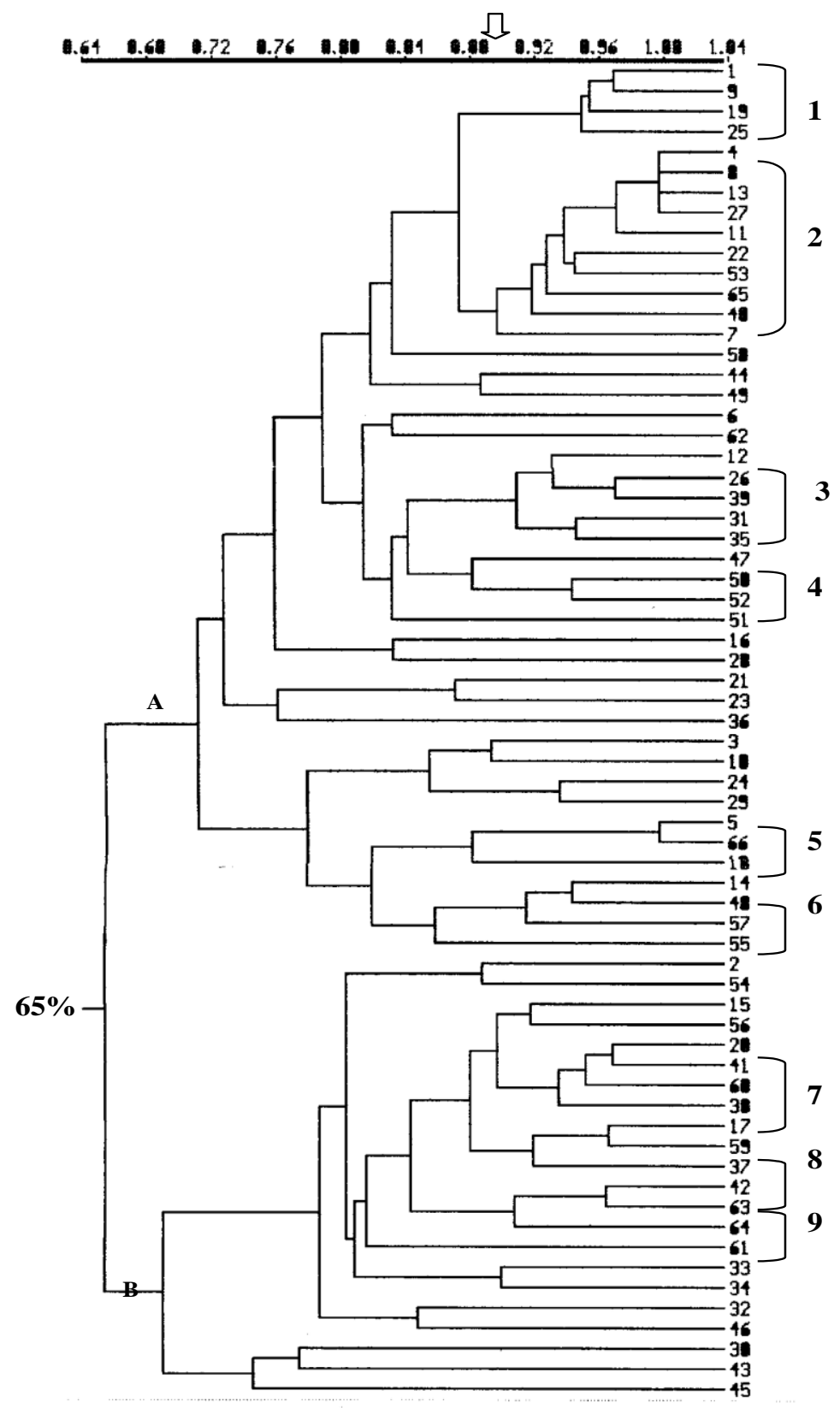

Figure 1. Dendogram and pulsotype of 66 S. typhi isolates

Dendogram showing the cluster among the 66 S. typhi isolates. Scale indicates level of genetic relatedness within this collections of isolates. Nine clusters (cluster 1 to 9) were determined at 90\% degree of similarity. Pulsotype was determined as described by Tenover (1997). ${ }^{13}$

Four identical isolates of pulsotype II were showing diverse clinical appearance as shown in Table 3 and Table 4. Similar conditions were also observed to the other 6 subtypes in the same pulsotype. On the other hand, distinct clusters happened to share several specific clinical manifestations. All typhoid complications apparently were derived from genetically diverse isolates. Below were 4 most common complications found from the patients and their etiologic pathogen in their pulsotypes and clusters: 
Table 3. Disease complications and the distribution of S. typhi in pulsotypes and clusters

\begin{tabular}{|c|c|c|c|c|c|}
\hline \multirow{2}{*}{ No. } & \multirow{2}{*}{ Complications } & \multirow{2}{*}{ Cases } & \multirow{2}{*}{ Pulsotype } & \multicolumn{2}{|c|}{ Cluster at degree of similarity } \\
\hline & & & & $90 \%$ & $65 \%$ \\
\hline 1 & Pancytopenia & 6 & $\mathrm{I}_{1}, \mathrm{II}, \mathrm{II}_{6}, \mathrm{III}, \mathrm{XXIV}_{3}, \mathrm{XXVI}_{1}$ & $1,2,7,9$ & $\mathrm{~A}, \mathrm{~B}$ \\
\hline 2 & Encephalopathy & 5 & $\mathrm{I}_{1}, \mathrm{I}_{2}, \mathrm{II}, \mathrm{XXI}$ & 1,2 & A, B \\
\hline 3 & Typhoid hepatitis & 4 & $\mathrm{I}_{1}, \mathrm{I}_{2}, \mathrm{XIX}, \mathrm{XXIII}$ & 1,6 & A \\
\hline 4 & Bronchopneumonia & 3 & II, XI, XIX 1 & 2,6 & A \\
\hline 5 & Bicytopenia & 2 & II, $\mathrm{XXV}_{2}$ & 2,8 & A, B \\
\hline 6 & Paralysis of N.VII & 2 & $\mathrm{II}_{2}$ & 2 & A \\
\hline 7 & Hematemesis \& melena & 2 & 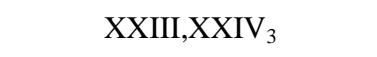 & 7 & B \\
\hline 8 & Acute Pancreatitis & 1 & XVII & - & A \\
\hline 9 & $\begin{array}{l}\text { Peritonitis e.c } \\
\text { perforation of the bowel }\end{array}$ & 1 & XXIII & - & B \\
\hline 10 & Fatal & 1 & XXIII & - & B \\
\hline 11 & Relaps & 1 & $\mathrm{VII}_{4}$ & 3 & A \\
\hline
\end{tabular}

Table 4. Clusters of closely related with $90 \%$ degree of similarity of $S$. typhi and their clinical presentations in Typhoid Fever patients

\begin{tabular}{|c|c|c|c|c|c|c|c|c|c|c|c|c|c|c|c|c|c|c|}
\hline \multirow{3}{*}{$\begin{array}{c}\text { Cluster (Pulsotype) } \\
\text { No. Isolates } \\
\text { Reported cases } \\
\end{array}$} & \multicolumn{2}{|c|}{$1(\mathrm{I})$} & \multicolumn{2}{|c|}{2 (II) } & \multicolumn{2}{|c|}{$3(\mathrm{VII})$} & \multicolumn{2}{|c|}{4 (VIII) } & \multicolumn{2}{|c|}{5 (XVIII) } & \multicolumn{2}{|c|}{$6(\mathrm{XIX})$} & \multicolumn{2}{|c|}{7 (XXIV) } & \multicolumn{2}{|c|}{$8(X X V)$} & \multicolumn{2}{|c|}{$9(\mathrm{XXVI})$} \\
\hline & \multicolumn{2}{|c|}{4} & \multicolumn{2}{|c|}{10} & \multicolumn{2}{|c|}{5} & \multicolumn{2}{|c|}{3} & \multicolumn{2}{|c|}{3} & \multicolumn{2}{|c|}{3} & \multicolumn{2}{|c|}{4} & \multicolumn{2}{|c|}{3} & \multicolumn{2}{|c|}{3} \\
\hline & $\mathrm{n}$ & $\%$ & $\mathrm{n}$ & $\%$ & $\mathrm{n}$ & $\%$ & $\mathrm{n}$ & $\%$ & $\mathrm{n}$ & $\%$ & $\mathrm{n}$ & $\%$ & $\mathrm{n}$ & $\%$ & $\mathrm{n}$ & $\%$ & $\mathrm{n}$ & $\%$ \\
\hline Fever & $4 / 4$ & 100 & $6 / 8$ & 75 & $3 / 3$ & 100 & $\mathrm{Nd}$ & $\mathrm{Nd}$ & $1 / 2$ & 50 & $2 / 2$ & 100 & $2 / 2$ & 100 & $2 / 2$ & 100 & $2 / 2$ & 100 \\
\hline Hepatomegaly & $1 / 4$ & 25 & $2 / 8$ & 25 & $2 / 2$ & 100 & $\mathrm{Nd}$ & $\mathrm{Nd}$ & $0 / 2$ & 0 & $1 / 2$ & 50 & $1 / 2$ & 50 & $0 / 2$ & 0 & $0 / 2$ & 0 \\
\hline $\begin{array}{l}\text { Leucopenia } \\
<5,000 / \mathrm{mm} 3\end{array}$ & $2 / 4$ & 50 & $6 / 8$ & 75 & $0 / 3$ & 0 & $1 / 1$ & 100 & $1 / 2$ & 50 & $2 / 2$ & 100 & $1 / 2$ & 50 & $1 / 2$ & 50 & $2 / 2$ & 100 \\
\hline $\begin{array}{c}\text { Leucocytosis } \\
>10,000 / \mathrm{mm} 3\end{array}$ & $1 / 4$ & 25 & $0 / 8$ & 0 & $0 / 3$ & 0 & $0 / 1$ & 0 & $0 / 2$ & 0 & $0 / 2$ & 0 & $0 / 2$ & 0 & $0 / 2$ & 0 & $0 / 2$ & 0 \\
\hline Normal leucocyte & $1 / 4$ & 25 & $2 / 8$ & 25 & $3 / 3$ & 100 & $0 / 1$ & 0 & $1 / 2$ & 50 & $0 / 2$ & 0 & $1 / 2$ & 50 & $1 / 2$ & 50 & $0 / 2$ & 0 \\
\hline $\begin{array}{c}\text { Thrombocytopenia } \\
<150,000 / \mathrm{mm} 3\end{array}$ & $3 / 4$ & 75 & $5 / 8$ & 62.50 & $2 / 3$ & 66.67 & $0 / 1$ & 0 & $1 / 2$ & 50 & $2 / 2$ & 100 & $2 / 2$ & 100 & $1 / 2$ & 50 & $1 / 2$ & 50 \\
\hline $\begin{array}{c}\text { Normal } \\
\text { Thrombocyte }\end{array}$ & $1 / 4$ & 25 & $3 / 8$ & 37.50 & $1 / 3$ & 33.33 & $1 / 1$ & 100 & $1 / 2$ & 50 & $0 / 2$ & 0 & $0 / 2$ & 0 & $1 / 2$ & 50 & $1 / 2$ & 50 \\
\hline $\begin{array}{l}\text { Thrombocytosis } \\
>500,000 / \mathrm{mm}^{3}\end{array}$ & $0 / 4$ & 0 & $0 / 8$ & 0 & $0 / 3$ & 0 & $0 / 1$ & 0 & $0 / 2$ & 0 & $0 / 2$ & 0 & $0 / 2$ & 0 & $0 / 2$ & 0 & $0 / 2$ & 0 \\
\hline $\begin{array}{l}\text { Increase SGOT } \\
>37 \mu \mathrm{mol} / /\end{array}$ & $4 / 4$ & 100 & $7 / 8$ & 87.50 & $2 / 2$ & 100 & $0 / 1$ & 0 & $2 / 2$ & 100 & $2 / 2$ & 100 & $1 / 1$ & 100 & $1 / 1$ & 100 & $2 / 2$ & 100 \\
\hline Normal SGOT & $0 / 4$ & 0 & $1 / 8$ & 12.50 & $0 / 2$ & 0 & $1 / 1$ & 100 & $0 / 2$ & 0 & $0 / 2$ & 0 & $0 / 1$ & 0 & $0 / 1$ & 0 & $0 / 2$ & 0 \\
\hline $\begin{array}{l}\text { Increase SGPT } \\
>41 \mu \mathrm{mol} / /\end{array}$ & $2 / 4$ & 50 & $3 / 8$ & 37.50 & $1 / 2$ & 50 & $0 / 1$ & 0 & $2 / 2$ & 100 & $2 / 2$ & 100 & $0 / 1$ & 0 & $1 / 1$ & 100 & $1 / 2$ & 50 \\
\hline Normal SGPT & $2 / 4$ & 50 & $5 / 8$ & 62.50 & $1 / 2$ & 50 & $1 / 1$ & 100 & $0 / 2$ & 0 & $0 / 2$ & 0 & $1 / 1$ & 100 & $0 / 1$ & 0 & $1 / 2$ & 50 \\
\hline $\begin{array}{c}\text { Increase } \\
\text { Bilirubin Total } \\
>1.1 \mathrm{mg} \%\end{array}$ & $2 / 4$ & 50 & $0 / 8$ & 0 & $0 / 2$ & 0 & $0 / 1$ & 0 & $0 / 2$ & 0 & $0 / 2$ & 0 & $0 / 1$ & 0 & $0 / 1$ & 0 & $0 / 2$ & 0 \\
\hline $\begin{array}{c}\text { Normal } \\
\text { Bilirubin Total } \\
0.1-1.1 \mathrm{mg} \%\end{array}$ & $2 / 4$ & 50 & $8 / 8$ & 100 & $2 / 2$ & 100 & $1 / 1$ & 100 & $2 / 2$ & 100 & $2 / 2$ & 100 & $1 / 1$ & 100 & $1 / 1$ & 100 & $2 / 2$ & 100 \\
\hline
\end{tabular}


1. Pancytopenia was detected from patients harboring $S$. typhi originated from pulsotypes $\mathrm{I}_{1}, \mathrm{II}, \mathrm{II}_{6}$, $\mathrm{XXIV}_{3}$ and $\mathrm{XXVI}_{1}$ in which at $90 \%$ degree of similarity gain in clusters 1, 2, 7 and 9

2. Encephalopathy was found in patients infected by S. typhi isolates designated by pulsotypes $\mathrm{I}_{1}, \mathrm{I}_{2}$ and II from clusters 1 and 2 at $90 \%$ degree of similarity

3. Typhoid hepatitis was found in pulsotypes $I_{1}, I_{2}$ and XIX or clusters 1 and 6 at 90\% degree of similarity

4. Bronchopneumonia may also was found in typhoid fever patients harboring pulsotype II and pulsotype $\mathrm{XIX}_{1} S$. typhi from cluster 2 and 6 at 90\% degree of similarity.

These observations thus far suggested no predominant symptoms were characteristic to any particular clusters. The same clinical symptoms could be found in different clusters. Even in other main cluster A, fatal case due to peritonitis caused by perforation of the bowel was found in patient infected by isolate designated by pulsotype XXIII originated from main cluster B. Four identical isolates, with pulsotype II belonged to cluster 2, showed diverse clinical symptoms pancytopenia, encephalopathy, bronchopneumonia and bicytopenia.

Beyond all these indistinctive clinical symptoms in relation to their genome characteristics of the pathogens, interestingly, 2 out of 4 cases infected by $S$. typhi belonged to cluster 1 were found to have an elevation of total bilirubin, while that same symptom was absent in other 19 patients harboring S. typhi originated from other 8 clusters.

\section{DISCUSSION}

Typhoid fever as an important public health problem is still an interesting topic to be explored extensively. Many epidemiological marker techniques to investigate the disease have been involved, and in the last few years it seemed that the applications of molecular techniques, especially PFGE, is currently favored for this etiological pathogens. $15,19,20,21,30,32,33$

Although this technique is time and cost consuming, PFGE showed high discriminatory ability and reproducibility and therefore is chosen to be an effective means of differentiating $S$. typhi strains. ${ }^{27,28,33}$

We analyzed 66 isolates of $S$. typhi obtained from sporadic hospitalized typhoid fever cases. As all of the isolates used in this investigation were sensitive to antibiotics tested, further study of this particular phenotype characteristic in relation to severity of typhoid fever was not further continued.

The results of the electrophoresis of all $S$. typhi DNA genome digested with $\mathrm{Xba \textrm {I }}$ were not different from our earlier investigation. ${ }^{20}$ Although, these isolates were collected from one hospital, and most isolates were designated as belonged to pulsotype II, a wide range of different pulsotypes have been found. Genetic relatedness among them varied which were shown by their Dice coefficients from 0.667 to 1.000 . Further, at $65 \%$ or above degree of similarity they were divided into 2 main clusters suggested they were genetically highly diverse and were not originated from a single clone. This finding supported the previous reports. Thong et $\mathrm{al}^{30}{ }^{30}$ provided some indications that there were considerable diversity among S. typhi strains circulating in Southeast Asia regions, particularly Malaysia, Indonesia and Thailand due to increasing mobility of travelers and migrant workers among these countries. The extent of genetic diversity among strains is actually greater than previously thought. The report also suggested that multiple clones of $S$. typhi were endemic in these regions, thus contrasting the concept that $S$. typhi is derived from a single clone. ${ }^{34,35}$

Clinical manifestations of those patients varied as described above. Variations of clinical manifestations in typhoid fever were assumed to be related to many intrinsic and extrinsic factors of the strains. Regarding to the intrinsic factors, we explored the clinical syndromes from patients within the same clusters. As there is no set criteria that are appropriate for every organisms and circumstances worldwide, $90 \%$ or above degree of similarity was chosen in this research to be a cut-off point to evaluate any possible existence of relationship between genetic profile and the varied clinical outcomes.

The symptoms observed in each of the 9 clusters with $90 \%$ or above degree of similarity were actually varied. Further, some of the disease complications such as pancytopenia, encephalopathy, typhoid hepatitis, bronchopneumonia were distributed diversely in all those clusters. Thong et al. ${ }^{14}$ suggested a correlation between certain pulsotypes of $S$. typhi from Papua New Guinea and the ability to cause fatal typhoid fever, while Franco et al. ${ }^{11}$ found specific flagellar types of $S$. typhi in Indonesia that were associated with severe outcomes of the disease. Nonetheless, 
the association between pulsotypes and clinical manifestations was statistically not significant.

Although there was seemed no clinical symptoms specifically related to any particular cluster in cluster 1 , we found $50 \%$ cases with elevated total bilirubin in which were absent in other 19 isolates from other 8 cluster. This finding assumed us that tendency of hepatobiliary symptoms was found in cluster 1 .

Acute pancreatitis has been observed in this study as shown by elevated serum amylase and lipase, found in patient infected by $S$. typhi isolate designated by pulsotyope XVII originated from main cluster A. Although typhoid pancreatitis were reported as a very rare complication of typhoid fever, but this complication sporadically appeared in the world reports in the last several decades. It seems that with the advance of modern technology such as improvement of blood amylase and lipase analysis and the availability of ultrasonographic and computer tomographic examinations, this rare complication was diagnosed more easily. Since the first report of typhoid pancreatitis in Indonesia in $1992,{ }^{36}$ the presence of this complications were reported more frequently. ${ }^{37}$ One fatal case was found in this study from patients harboring S. typhi pulsotype XXIII from main cluster B.

This study, thus far, showed no apparent relationship between pulsotype and the clinical symptoms, and no plausible explanations as yet to suggest the presence of diverse range of symptoms produced by the closely related microorganisms belonged to particular clusters to each host. Nonetheless, it is interesting to further elaborate the possibility of the presence of characteristic pulsotypes of $S$. typhi, which showed hepatobiliary trophism as suggested by pulsotypes $\mathrm{I}_{1}$ and $\mathrm{I}_{2}$ of $S$. typhi in cluster 1 .

However, the mystery of pathogenesis of this microorganism is still interesting to be explored extensively and some promising and innovative approaches are still needed for further study.

\section{REFERENCES}

1. Thong KL, Yong FY, Puthucheary SD, Koh CL, Sudarmono P, et al. Molecular analysis of Salmonella typhi from Southeast Asia using pulse-field gel electrophoresis. SEAMEO 1995; 26 (Supp. 2): 29-32.
2. Aryoso S, Simanjuntak CH. Typhoid fever and salmonellosis in Indonesia. In: Sudarmono P, Punjabi N, Sudiro TM. Proceeding of the $3^{\text {rd }}$ Asia-Pacific Symposium on typhoid fever and other salmonellosis. Med. J. Indones. 1998; 7 (Supp 1): 20-3.

3. Jakarta Dalam Angka. Jakarta. Badan Pusat Statistik. 1999: 156

4. Sumara SI, Evaluation of laboratory data on salmonella infections during 1984-1990 from the public health laboratory of Perum Bio Farma (Pasteur Institute) Bandung. In. Nelwan RHH: Typhoid fever. Profile, diagnosis and tretment in 1990's. Acta Medica Indonesiana. Jakarta. FKUI Press.. 1992; 211-24.

5. Mandal BK. Salmonella infections. In: Cook G. Manson's Tropical Disease. $20^{\text {th }}$ Ed. London. WB Saunders. 1996: 849-63.

6. D'Aoust. JY. Salmonella spesies. In: Doyle MP. Beuchat LR, Montville TJ. Food microbiology. Fundamentals and frontiers. Washington DC. ASM Press. 1997: 129-58.

7. Ochman H, Groisman EA. Distribution of pathogenicity islands in Salmonella spp. Infect.Immunol. 1996; 64(12): 339-42.

8. Khosla SN. Severe typhoid fever and appraisal of its profile. In: Nelwan RHH. Typhoid fever : Profile, diagnosis and treatment in 1990's. Jakarta. Acta Medica Indonesiana. $1992:$ 51-81.

9. Punjabi N. Prolonged fever in typhoid fever: Role of hostparasite interaction. In: Sarasombath S, Senawong S. 2nd Asia-Pacific symposium on typhoid fever and other salmonellosis. Southeast Asia J. Trop.Med.Pub.Health. 1995; 26 (Suppl 2): 150-9.

10. Pang T. Genetic dynamic of Salmonella typhi diversity in clonality. Trends Microbiol . 1998; 6 (9): 339-42.

11. Franco A, Gonzales C, Levine OS, et al. Further consideration of the clonal nature of Salmonella typhi: Evaluation of molecular and clinical characteristics of strains from Indonesia and Peru. J. Clin. Microbiol. 1992; 30(8): 2187-90.

12. Moehario LH, Firdaus ES, Sudarmono P. Assessment of reactivities of typhoid fever sera against outer membrane protein preparations from strains of Salmonella typhi in Jakarta. In: Sudarmono P. Punjabi N, Sudiro TM. Proceeding of the $3^{\text {rd }}$ Asia-Pacific Symposium on typhoid fever and other salmonellosis. Med. J. Indones. $1998 ; 7$ (Supp.1): 44-8

13. Calva E, Puente JL. S. typhi outer membrane proteins : Their roles in typhoid fever. In: Sarasombath S, Senawong S. $2^{\text {nd }}$ Asia-Pacific symposium in typhoid fever and other salmonellosis. South Asia J. Trop.Med.Pub.Health. 1995; 26 (Supp 2): 138-44.

14. Ismail A, Kader ZSA, Hai OK. Development of a dot enzyme immunosorbent assay (EIA) for the rapid diagnosis of the typhoid fever. In: Pang T, Koh CL, Puthucheary SD. Typhoid fever. Strategies for the 90's. Singapore. World Scientific Publishing Co. Pte. Ltd. 1992: 201-6.

15. Thong KL, Passey M, Clegg A, Combs BG, et al, Molecular analysis of isolates of Salmonella typhi obtained from patients with fatal and nonfatal typhoid fever. J. Clin. Microbiol. 1996; 34: 1029-33. 
16. Sub Bagian Rekam Medis Bagian Perencanaan dan Informasi. Kegiatan Layanan Medis Tahuin 1998. Jakarta. Rumah Sakit Umum Pusat Persahabatan . 1998.

17. Ferraro MJ, Craig WA, Dudley MN, Eliopoulos G, et al. Eleventh International Supplement. In: Performance Standards for Antimicrobial Susceptibility Testing. Pennsylvania USA, The National Committee for Clinical Laboratory Standards (NCCLS). 2001; 21(1): 27-44

18. Suwanto A and Kaplan S. Physical and genetic mapping of the Rhodobacter sphaeroides 2.4.1 genome. Genome size, fragment identification and gene localization. J. Bacteriol.1989;171(11): 5840-9.

19. Thong KL, Cheong YM, Puthucheary S, Koh CL, et al. Epidemiologic analysis of sporadic Salmonella typhi isolates and those from outbreaks by pulse-field gel electrophoresis. J. Clin. Microbiol. 1994; 32(5): 1135-41.

20. Moehario LH, Soemanto RK. Study of genetic diversity of Salmonella typhi using pulse-field fel electrophoresis. Med. J. Indones. 2001; 10 (3): 158-63.

21. Koay AS, Jegathesan M, Yassin RM, Cheong YM. Pulsefield gel electrophoresis as an epidemiologic tool in the investigation of laboratory acquired Salmonella typhi infection. Southeast Asia. J. Trop. Med. Pub. Health. 1997; 28 (1): 82-4.

22. Martin R. Pulse-field gel electrophoresis. In: Gel electrophoresis: Nucleic Acids. Singapore. Toppan- Bios Scientific Publishers. 1996: 107-15.

23. Maslow JN, Slutsky AM, Arbeits RD. Appication of pulse-field gel electrophoresis to molecular epidemiology. In: Persing DH, Smith TF, Tenover FC, White TJ. Diagnostic molecular microbiology. Principles and applications. Washington DC. ASM Press. 1993: 563-72

24. Struelens MJ, et al. ESCMID study group report: Consensus guidelines for appropriate use and evaluation of microbial epidemiologic typing systems. Clin. Microbiol. Infect.1996; 2(1): 2-11.

25. Suwanto A. A phisical and genetic mapping of the Rhodobacter sphaeroides 2.4.1 genome: Genome size, fragment identification and gene location. J.Bacteriol. 1989; 171 (11): 5840-9.

26. Swaminathan B B, Matar GM. Molecular typing methods. In: Persing DH, Smith TF, Tenover FC, White TJ. Diagnostic molecular microbiology : Principles and application. Washington DC. ASM Press. 1993 : 26-50.

27. Tenover FC, Arbeit RD, Goering RV, The Molecular Typing Working Group of the Society for Healthcare Epidemiology of America. How to select and interpret molecular strain typing methods for epidemiological studies of bacterial infections: A review for healthcare epidemiologists. Infec.Control and Hosp. Epidemiol 1997; 18: 426-9.

28. Tenover FC, Arbeit RD, Goering RV, Mickelsen PA, et al. Interpreting chromosomal DNA restriction patter produced by pulse-field gel electrophoresis: Criteria for bacterial strain typing. J. Clin.Microbiol. 1995; 33(9): 2233-9.

29. Zadoks R, van Leeuwen W, Barkema, et al Application of pulse-field gel electrophoresis and binary typing as tools in veterinary clinical microbiology and molecular epidemiologic analysis of bovine and human Staphylococcus aureus isolates. J. Clin. Microbiol. 2000; 38(5): 1931-9.

30. Thong KL, Puthucheary, Yassin RM, Sudarmono P, et al. Analysis of Salmonella typhi isolates from Southeast Asia by pulse-field gel electrophoresis. J. Clin. Microbiol. 1995; 33(7): 1938-41.

31. Rohlf FJ. NTSYS - pc. Numerical Taxonomy and Multivariate Analysis System Version 1.80. New York. Exeter Software.1993.

32. Murase T, Okitsu T, Suzuki R, Morozumi H, et al. Evolution of DNA fingerprinting by PFGE as an epidemiologic tool for Salmonella infections. Microbiol. Immunol. 1995; 39(9): 673-6.

33. Nishiumi H, Lin CL, Kondo F, Saltanu K, et al. Epidemiological studies of Salmonella isolated from various sources by plasmid and genomic DNA analysis using conventional and pulse-field gel electrophoresis. SEAMEO 1995; 26 (Supp 2): 45-8.

34. Reeves MW, Evins GM, Heiba AA, Plikaytis BD, et al. Clonal nature of Salmonella typhi and its genetic relatedness to other Salmonellae shown by multilocus enzyme electrophoresis and proposal of Salmonella bongori comb.nov. J.Clin.Microbiol 1989;27(2):313-20.

35. Selander RK, Beltrans P, Smith NH, et al. Evolutionary of genetic relationships of clones of Salmonella serovars that cause human typhoid and other enteric fevers. Infect Immun. 1990; 58: 2262-75.

36. Nelwan RHH. Typhoid pancreatitis. In : Nelwan RHH. Typhoid fever. Profile, diagnosis and treatment in 1990s. Acta Medica Indonesiana. Jakarta. FKUI Press. 1992: 105-12.

37. Nelwan RHH. Changing pattern of typhoid fever complications in Indonesia. In: Sudarmono P, Punjabi N, Sudiro TM, Proceeding of the $3^{\text {rd }}$ Asia-Pacific Symposium on typhoid fever and other salmonellosis. Med. J. Indones. 1998;7 (Supp.1): 105. 


